\title{
An Image Processing Approach for Detection, Quantification, and Identification of Plant Leaf Diseases -A Review
}

\author{
Prabira Kumar Sethy ${ }^{\# 1}$, Baishalee Negi ${ }^{* 2}$, Santi Kumari Behera ${ }^{\# 3}$, \\ Nalini Kanta Barpanda ${ }^{\# 4}$, Amiya Kumar Rath ${ }^{\# 5}$ \\ 1,2,4 SUIIT, Sambalpur University, Jyoti Vihar, Odisha, India-768019 \\ ${ }^{3,5}$ Department of Computer Science and Engineering, VSS University, Odisha, India-768018 \\ prabirsethy.05@gmail.com¹, baishalee.negi@suiit.ac.in², b.santibehera@gmail.com³ \\ nkbarpanda@suiit.ac.in ${ }^{4}$, amiyaamiya@rediffmail.com ${ }^{3}$ \\ *Phone: +91-9439489214
}

\begin{abstract}
Disease detection and health monitoring on the plant are very critical issue for sustainable agriculture. This paper aims to analyze different methods that are used in image processing techniques to detect, classify \& quantify plant leaf diseases from digital images. In this paper, the authors evaluate mainly in three well regulated manners: first Detection of Leaf Disease, second Classification i.e. recognizes the type of disease and the last one is Quantification of Disease i.e. measures the severity of Disease. The findings of authors and limitations in each methodology with respect to applications are consolidated. Each methodology has its unique way of usefulness apart from its limitations. Most of the times some pre-processing technique as enhancement, feature extraction, and noise removal techniques need to introduce to detect the leaf disease are compared here. An identification issue deals with associating a given input pattern with one of the distinct classes. So, there is various successful machine learning and soft computing techniques to classify the disease. Deciding on the method for identification is often a difficult task because the quality of the results can be varying for different input data. The review also considers disease severity to predict yield loss and monitoring \& forecasting epidemics, for assessing crop disease resistance. This review considers leaf disease severity assessment of plant at the scale of individual and defines our current understanding of the sources which need some more improvements.
\end{abstract}

Keywords-Image processing, Plant leaf disease detection \& classification, Quantification of plant leaf disease.

\section{INTRODUCTION}

Plant disease is considered as the most important dilemma all over the world because the economic growth of the majority of the developing countries is depends upon the agriculture. So, the crop losses in the developing countries like India which run to millions of dollars affect adversely the country economy and nutritional standard because almost $70 \%$ of the population of Indian depend on it. The condition is all the more critical considering the facts that all the affords made by these countries in producing more food grain are vitiated by substantive pre-harvest crop losses due to diseases. Crops are often infested by some diseases caused by some pathogens including fungi, bacteria, and viruses. So, monitoring of healthy or disease on plant plays an important role in the successful cultivation of in the field. In the early days, the monitoring and diagnosis of plant disease were done by the expert person in the field is time taking and not reliable method. To overcome this problem the agriculture research is going on for developing an automated system for disease detection and diagnosis purpose. It is estimated that losses due to plant disease in Georgia (USA), 2007 is approximately $\$ 539.74$ million. Around of 185 million USD was spent on controlling the plant diseases, and the rest is the value of damage caused by the diseases. Table 1 is an illustration ${ }^{[1]}$. 
Table 1. Summary of yield losses (\%) due to different diseases

\begin{tabular}{|l|l|l|}
\hline \multicolumn{1}{|c|}{ Crop } & Value of damage (\$ millions) & Cost of Control \\
\hline Apple & 0.073 & 0.267 \\
\hline Blueberry & 0.14 & 2.555 \\
\hline Bunch Grape & 0.112 & 0.27 \\
\hline Corn & 12.4 & 0.5 \\
\hline Cotton & 81.7 & 12.2 \\
\hline Wheat & 0.99 & 1.8 \\
\hline Ornamental & 41.22 & 21.2 \\
\hline Soybean & 5.3 & 1.9 \\
\hline Peach & 0.177 & 3.19 \\
\hline Peanut & 58.7 & 41.2 \\
\hline
\end{tabular}

The research in image processing techniques for detection of plant leaf diseases going on since past decade. There are different methods have been proposed to study about plant diseases using image processing techniques $^{[2]}$. The main objective to increase the accuracy by reducing the error which is made by the human experts to detect and recognize the plant diseases. Figure $1^{[3]}$ represents a framework for detection and classification of plant leaf diseases.

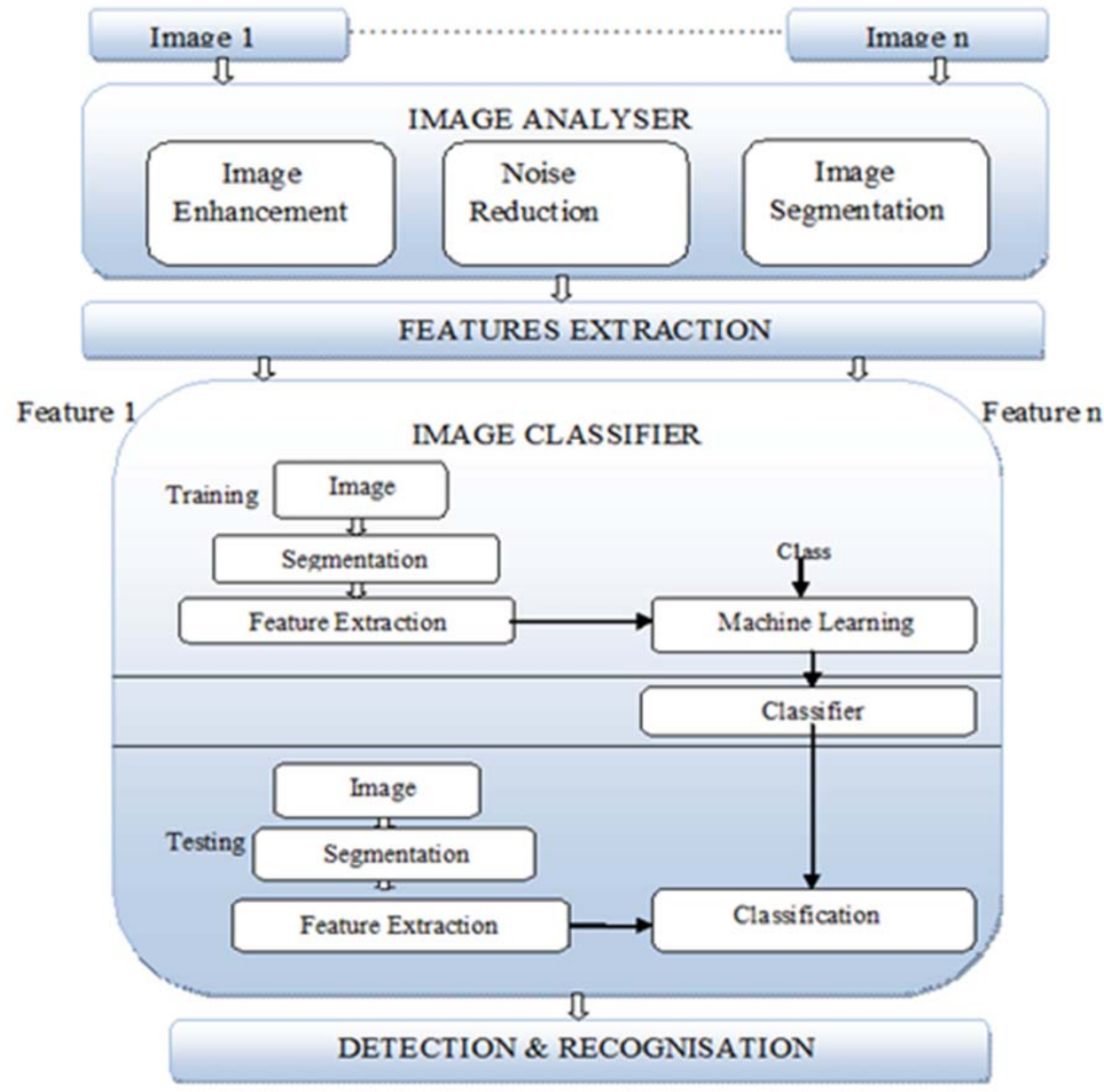

Figure 1. Framework for detection and classification of plant leaf diseases

In order to manage plant leaf diseases effectively, there is required to introduce an automatic method of plant surveillance that can scrutinize plant condition and apply the knowledge-based solution to detect and classifying various diseases. A variety of methodologies has been proposed recently for detection and classification of plant diseases from images using machine learning techniques ${ }^{[4]}$. Since there are challenges of accuracy and robustness that need to be at rest to fulfill practical benefits from these techniques. This report presents experimental results of plant leaf disease identification and classification using various machines learning 
techniques. Figure 2 show the basic set up of automated plant leaf disease analysis using, machine learning technique. The general system for detection and reorganization of plant leaf disease consist of three main components; image analyzer, feature extraction, and classifier. In this step input images of the leaf (diseased \& healthy) were processed by the image analyzer and certain features are extracted. Then these features are given as input to the classifier and along with it the information whether the image is a diseased or healthy leaf. Then the classifier finds the relation among the features extracted and possible conclusion above occurrence of the disease. Thus the system is trained.

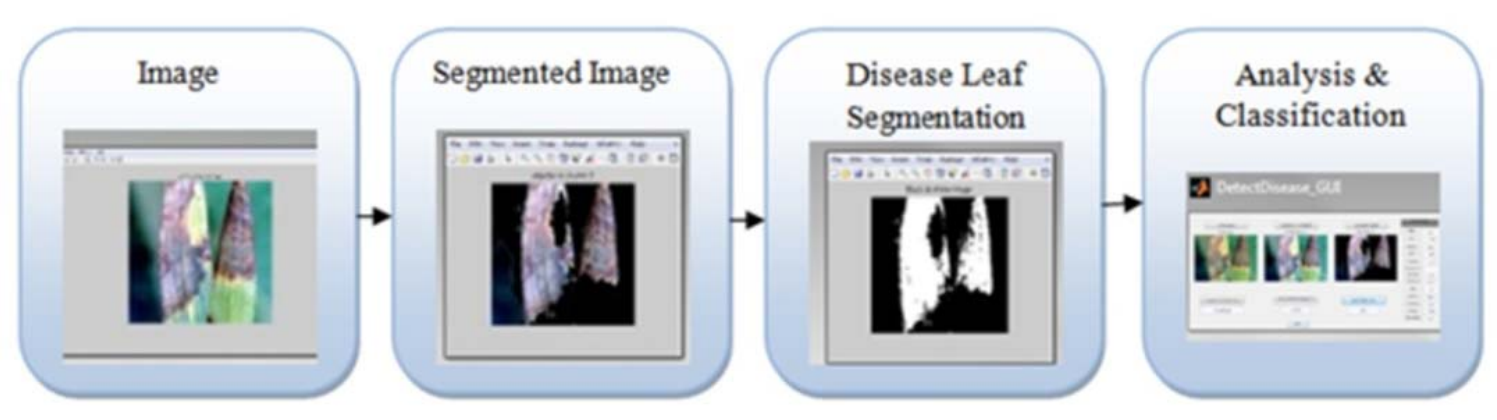

Figure 2. Detection and classification of rice leaf diseases

This report explores, each of the stages involves and represents all the techniques that have been assimilated in each stage all research work has been done till date on detection, classification, and quantification of plant leaf diseases. Some of the plant leaf diseases, aim to detect, diagnosis and classify in this report is shown in Table 2.

Table 2. Detection \& Classification of some leaf diseases already has been discussed till date

\begin{tabular}{|c|c|}
\hline Plant Leaf & \begin{tabular}{|c|} 
Diseases of Leaf Considered \\
\end{tabular} \\
\hline Apple & Apple mosaic, Apple rust, and Apple Alternaria leaf spot ${ }^{[5]}$ \\
\hline Cassava & Brown leaf spot ${ }^{[6]}$ \\
\hline Citrus & Citrus canker $^{[7],[8],[9]}$ \\
\hline Cotton & $\begin{array}{l}\text { a) Bacterial disease: e.g. Bacterial Blight, Lint Degradation, Crown Gall. } \\
\text { b) Fungal diseases: e.g. Leaf Spot, Anthracnose. } \\
\text { c) Viral disease: e.g. Leaf Crumple Leaf Curl, Leaf Roll. } \\
\text { d) Diseases Due To insects: e.g. White flies Leaf insects } \\
\text { e) Leaf Crumple, Red Spots }{ }^{[11]}\end{array}$ \\
\hline Ground Nut & iron, zinc and magnesium deficiencies ${ }^{[12]}$ \\
\hline Maize & Gray spot \& common rust disease ${ }^{[13]}$ \\
\hline Rice & $\begin{array}{l}\text { Brown-Spot Disease (BSD), Blast Disease (BD), and Narrow Brown-Spot } \\
\text { Disease (NBSD) }{ }^{[14],[15]}\end{array}$ \\
\hline Sugarcane & Fungi-caused brown spot disease $^{[16]}$ \\
\hline Tomato & Tomato Early Blight, Late Blight Septoria Leaf Spot ${ }^{[17]}$ \\
\hline Other & Early scorch, Cottony mold, ashen mold, late scorch, tiny whiteness $^{[18]}$ \\
\hline
\end{tabular}

\section{IMAge ACQUisition PhASE}

The leaf images are captured through the camera such as Nikon camera P510 $0^{[19]}$, Nikon Cool pix L2 $0^{[20]}$, Nikon Cool pix P4 $4^{[15]}$.This image is stored in RGB (Red, Green \& Blue) form. Color transformation of RGB leaf image is created and then a device independent color space transform is applied ${ }^{[20]}$. The light intensity are avoided by two methods,

$>$ Keeping the leaf to be captured in a black box ${ }^{[21]}$.

$>$ By placing leaf on a white background with light sources at $45^{\circ}$ each side of the leaf to introducing better brightness and eliminate reflection ${ }^{[16]}$. 


\section{III.IMAGE ENHANCEMENT TECHNIQUE}

The objective of image enhancement is transforming the RGB image to a suitable color space which is device independent in nature. Before transforming the input leaf image into suitable color transform, first the acquired leaf image will be resized. Then the image will convert to a suitable color space on which the required information can be easily extracted more efficiently.

i. HIS color space: - HIS color space is most popular color transformation technique which used by many authors $^{[7],[22],[23]}$ to enhance the consider input image and the required equation for color transformation is given below equation 1-3.

$$
\begin{gathered}
H=\frac{\frac{1}{2}[(R-G)+(R-B)]}{\left[(R-G)^{2}+(R-B)(G-B)\right]^{\frac{1}{2}}} \\
I=\frac{(R+G+B)}{3} \\
S=1-\frac{3[\min (R, G, B]}{(R+G+B)}
\end{gathered}
$$

ii. Y1Y2 color space: - The captured image can be transformed to Y1 \& Y2 representation Qing Yao et al. ${ }^{[14]}$ where $\mathrm{Y} 1$ \& $\mathrm{Y} 2$ represented two color functions defines in below equations 4-5.

$$
\begin{aligned}
& \mathrm{Y} 1=2 \mathrm{~g}-\mathrm{r}-\mathrm{b} \\
& \mathrm{Y} 2=2 \mathrm{r}-\mathrm{g}-\mathrm{b}
\end{aligned}
$$

Where, R, G, and B represented pixel values of Red, Green and Blue (RGB) color image respectively.

iii. I1I2I3 color space: - Another option for creation of device independent color space transformation structure is I1I2I3 color space can be used by A. Camargo and J.S. Smith ${ }^{[24]}$. This color space is also applied on images of plant leaf and it works very well.

$$
\begin{aligned}
\mathrm{I} 1 & =\frac{\left(\mathrm{I}_{\mathrm{R}(\mathrm{i}, \mathrm{j})}+\mathrm{I}_{\mathrm{G}(\mathrm{i}, \mathrm{j})}+\mathrm{I}_{\mathrm{B}(\mathrm{i}, \mathrm{j})}\right)}{3} \\
\mathrm{I} 2 & =\frac{\left(\mathrm{I}_{\mathrm{R}(\mathrm{i}, \mathrm{j})}-\mathrm{I}_{\mathrm{B}(\mathrm{i}, \mathrm{j})}\right)}{2} \\
\mathrm{I} 3 & =\frac{\left(\left(2 * \mathrm{I}_{\mathrm{G}(\mathrm{i}, \mathrm{j})}\right) \sum\left(\mathrm{I}_{\mathrm{R}(\mathrm{i}, \mathrm{j})} \sum \mathrm{I}_{\mathrm{B}(\mathrm{i}, \mathrm{j})}\right)\right.}{3}
\end{aligned}
$$

iv. $\mathrm{H} I 3_{a} I 3_{b}$ color space: - Again by varying the parameter I3 mentioned in above equation (8), another color space can be achieved to gather more information ${ }^{[23]}$.

$$
\begin{aligned}
H= & \frac{60 *\left(I_{G(i, j)}-I_{B(i, j)}\right)}{m x-m i n} I_{R(i, j)}>\max \left(I_{G(i, j)} I_{B(i, j)}\right) \\
& \frac{180 *\left(I_{B(i, j)}-I_{R(i, j)}\right)}{m x-m i n} I_{G(i, j)}>\max \left(I_{B(i, j)} I_{R(i, j)}\right) \\
& \frac{360 *\left(I_{R(i, j)}-I_{G(i, j)}\right)}{m x-\min } I_{B(i, j)}>\max \left(I_{R(i, j)} I_{G(i, j)}\right) \\
I_{3}= & \frac{\left(\left(2.5 * I_{G(i, j)}\right)-I_{R(i, j)}-I_{B(i, j)}\right.}{4} \\
I_{b}= & \frac{\left(\left(2 * I_{G(i, j)}\right)-I_{R(i, j)}-I_{B(i, j)}\right.}{4}
\end{aligned}
$$

Where, $I 3_{a}=\frac{\left(\left(m * I_{G(i, j)}\right)-I_{R(i, j)}-I_{B(i, j)}\right.}{d e}, m \&$ de values are to be optimized.

$$
\begin{array}{r}
\operatorname{mx}(i, j)=\max \left(I_{G(i, j)}, I_{G(i, j)}, I_{B(i, j)}\right) \\
m n(i, j)=\min \left(I_{G(i, j)}, I_{G(i, j)}, I_{B(i, j)}\right)
\end{array}
$$

v. LAB color space: - ' $\mathrm{L}$ ' '*a' '*b' color space is also very useful color transformation technique to extract more information from the image by Piyush Chaudhary et al. ${ }^{[23]}$. This color space consists of luminosity layer ' $L$ ', chromaticity layer '*a' and ' $b$ ', where all the color information is present. This color space is very useful for color based image enhancement.

$$
\begin{aligned}
L & =116 f\left(\frac{Y}{Y_{n}}\right)-16 \\
a^{*} & =500\left(f\left(\frac{X}{X_{n}}\right)-f\left(\frac{Y}{Y_{n}}\right)\right) \\
b^{*} & =200\left(f\left(\frac{Y}{Y_{n}}\right)-f\left(\frac{Z}{Z_{n}}\right)\right)
\end{aligned}
$$

So, summarization of image enhancement techniques are illustrated below in Table 3. 
Table 3. Summary of different image enhancement techniques

\begin{tabular}{|c|c|c|}
\hline Authors Name & Proposed Methodology & Applications \\
\hline $\begin{array}{l}\text { S. Ananthi and S. Vishnu Varthini (2012) } \\
\text { P. Kumsawat et al. (2008) } \\
\text { Min Zhang, Qinggang Meng (2010) }\end{array}$ & HIS color space & $\begin{array}{ll}- & \text { Grape Leaf } \\
\text { - } & \text { Citrus canker }\end{array}$ \\
\hline Qing Yao et al. (2009) & Y1Y2 color space & - $\quad$ Rice Leaf \\
\hline A. Camargo and J.S. Smith (2008) & I1I2I3 color space & $\begin{array}{ll}\text { - } & \text { Cotton Leaf } \\
\text { - } & \text { Corn Leaf } \\
\text { - } & \text { Banana Leaf }\end{array}$ \\
\hline A. Camargo, J.S. Smith (2008) & $\mathrm{H} / 3_{a} I 3_{b}$ color space & $\begin{array}{ll} & \text { Cotton Leaf } \\
\text { - } & \text { Corn Leaf } \\
\text { - } & \text { Banana Leaf }\end{array}$ \\
\hline Piyush Chaudhary et al. (2012) & LAB color space & $\begin{array}{ll}\text { - } & \text { Rice Leaf } \\
\text { - } & \text { Soybean Leaf } \\
\text { - } & \text { Blueberry Leaf } \\
\text { - } & \text { Cotton Leaf }\end{array}$ \\
\hline
\end{tabular}

\section{IV.NOISE REDUCTION TECHNIQUE}

Image de-noising is a very important task in image processing. The techniques generally used to remove unnecessary noise from the input leaf image.

i. Mean Filter: - The mean filter is a simple spatial filter which acts on an image by smoothing it. This filter used on Rice ${ }^{[15]}$ leaf images.

ii. Median Filter: - The Median filter is simple and power non-linear filter which is based on order static, whose response is based on the ranking the values of pixel contained in the filter region. So, this method is easy to implement for smoothing images. A $3 * 3$ rectangle window is applied on the Rice leaf image ${ }^{[14]}$.

iii. Gaussian Filter: - Gaussian filter is used to remove noise and blurring of image. The Gaussian filter is a non-uniform low pass filter. It is more effective at smoothing an image. It's also used on Pomegranate leaves $^{[26]}$ for noise removal purpose.

iv. Anisotropic Diffusion: - The input image is enhanced by the anisotropic technique to preserve the information of extracted pixels before extracting leaf color from the background and ' $\mathrm{b}$ *' components from HIS and LAB color space respectively which reduce the effect of illumination ${ }^{[27]}$.

v. Morphological Operation: - Morphological operation involves erosion and dilation process. It is a very useful noise removal operation which is used on Cassava leaf image ${ }^{[6]}$.

So, summarizations of noise reduction techniques are illustrated below in Table 4.

Table 4. Summary of different noise reduction methods

\begin{tabular}{|l|l|l|}
\hline \multicolumn{1}{|c|}{ Authors Name } & Proposed Methodology & \multicolumn{1}{c|}{ Applications } \\
\hline $\begin{array}{l}\text { S. Phadikar, J. Sil, and A. K. Das (2012) } \\
\text { Mrunalini R. Badnakhe \& Prashant R. } \\
\text { Deshmukh (2012) }\end{array}$ & Mean Filter & $\begin{array}{l}\text { Spatial filter } \\
\text { Used for smoothing image }\end{array}$ \\
\hline Qing Yao, Zexin Guan et al. (2009) & Median Filter & $\begin{array}{l}\text { Nonlinear digital filter } \\
\text { Used for smoothing image }\end{array}$ \\
\hline Sanjeev S Sannakki et al. (2011) & Gaussian Filter & $\bullet \begin{array}{l}\text { Spatial filter } \\
\text { Used to blur images }\end{array}$ \\
\hline $\begin{array}{l}\text { Kittipong Powbunthorn, Wanrat } \\
\text { Abudullakasim and Jintana Unartngam } \\
(2012)\end{array}$ & Morphological Operation & $\bullet \begin{array}{l}\text { Nonlinear filter } \\
\text { Remove noise }\end{array}$ \\
\hline $\begin{array}{l}\text { Mr. V. A. Gulhane \& Dr. A. A. Gurjar } \\
(2011)\end{array}$ & Anisotropic Diffusion & $\bullet \begin{array}{l}\text { Partial derivatives } \\
\text { equations (PDE) based de- } \\
\text { noising }\end{array}$ \\
\hline
\end{tabular}

Figure 3 show an example of input image, binary image with noise and noise free binary image of Rice leaf. 

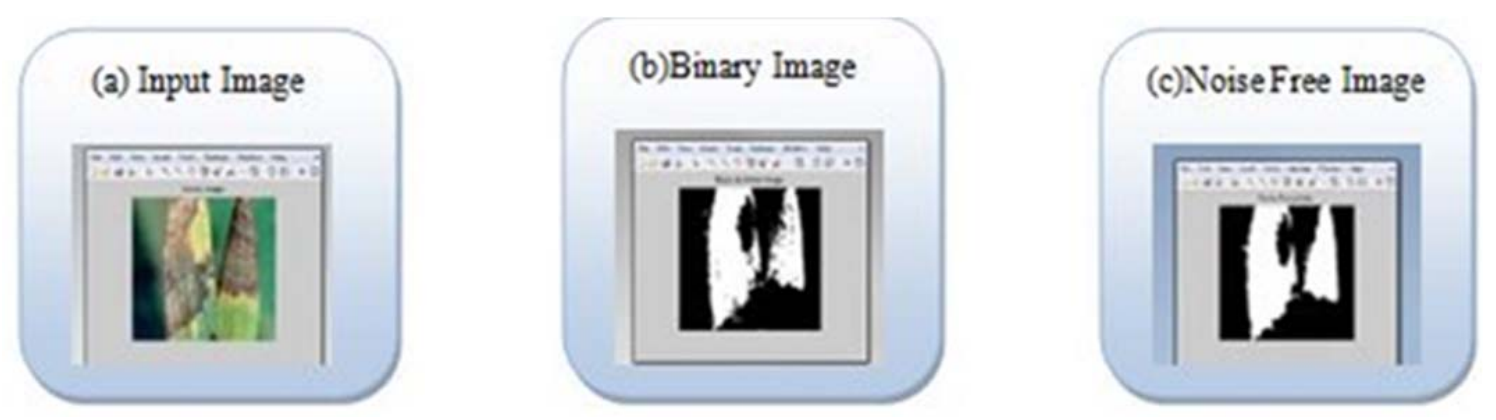

Figure 3. (a) Input Image, (b) Binary Image with Noise, (c) Binary Image with Noise free of diseased rice leaf

\section{IMAge Segmentation Technique}

Image segmentation is an important step in image analysis. Object recognition, features extraction, pattern recognition and many other tasks in image processing can be executed after the image segmentation phase. The aim of segmentation is to simplification of the image representation into more meaningful way and it is very easier to analysis. Image segmentation is a process, where every pixel presents in an image is assign by a label so that same label of pixels shares the visual characteristics.

i. Otsu's Method: - It is an optimum global thresholding segmentation method. Otsu's method defined as a weighted sum of variances of the two classes which minimizes the intra-class variance ${ }^{[28]}$. Otsu's thresholding method operates directly on the gray level image [i.e. 256 number of pixel]. The main idea is that, the well threshold classes should be distinct with respect to the intensity value of the pixels and conversely, that thresholding giving the best separation between classes in terms of their intensity value. Otsu's method is mostly applied on 'I' plane of HIS color space ${ }^{[6]}$. With few exception, such as the application of the method on ' $\mathrm{H}$ ' plane ${ }^{[15]}$ or on all planes in the transformed color space ${ }^{[14]}$. Also, Otsu's method is applied to Y1 \&Y2 color space representation ${ }^{[14]}$ of the color leaf image of the rice crop.

ii. K-Means Clustering Method: - K-Means algorithm is a numerical, iterative, unsupervised, and nondeterministic method. K-Means clustering algorithm is based upon the index of similarities or dissimilarities between pairs of the data component. In this clustering process, data is clustered iteratively by computing intensity for each group and by classifying each pixel in the class with the closest pixel the image has been segmented. K-Means clustering is used to segment the leaf image into cluster such one ${ }^{[20]}$ or more than one cluster contain the disease ${ }^{[29],[30]}$.

iii. Local Entropy Based Thresholding Method: - Local entropy in information theory ${ }^{[31]}$ represents the variance local region and catches the natural properties of the transition region. Transition region locates between the object and background. Transition region has certain width whether step edge or nonstop-edge. Transition regions around nonstop-edges have a certain number of pixel's width and step edges have at least one pixel's width.

iv. Neural Network Based Method: - In neural network based image segmentation, first the image is converted into energy minimization and then the neural network has been trained with training sample set in order to determine the weights and connection between the nodes. Various kind of neural network are used for image segmentation are BPNN (Back Propagation Neural Network), FFNN (Feed Forward Neural Network), MLP (Multi Layer Perceptron), SOFM (Self Organized Feature Map). The unsupervised SOFM network and Back Propagation neural network is applied to extract leaf color from the diseased part of the image. The approach has been applied for segmentation of leaf images of $\operatorname{cotton}^{[10]}$ and grape ${ }^{[23]}$. 
So, summarizations of image segmentation techniques are illustrated below in Table 5.

Table 5. Summary of different image segmentation techniques

\begin{tabular}{|c|c|c|c|}
\hline Authors Name & Proposed Methodology & Advantages & Disadvantages \\
\hline $\begin{array}{l}\text { Qing Yao, Zexin Guan et al. } \\
(2009) \\
\text { S. Phadikar, J. Sil, and A. K. Das } \\
\text { (2012) } \\
\text { Kittipong Powbunthorn, Wanrat } \\
\text { Abudullakasim et al. (2012) }\end{array}$ & Otsu's Method & Simple to implement. & $\begin{array}{l}\text { Otsu algorithm fails } \\
\text { when the global } \\
\text { distribution occurs. }\end{array}$ \\
\hline $\begin{array}{l}\text { S. Bani-Ahmad, M. Reyalat et al. } \\
\text { (2011) }\end{array}$ & $\begin{array}{l}\text { Local Entropy Based } \\
\text { Thresholding Method }\end{array}$ & Applied on histogram & $\begin{array}{l}\text { Two images with } \\
\text { same image } \\
\text { histogram yields } \\
\text { same threshold but in } \\
\text { practice this is not } \\
\text { correct. }\end{array}$ \\
\hline $\begin{array}{l}\text { Sanjeev S Sannakki et al. (2011) } \\
\text { Dheeb Al Bashish, Malik Braik, } \\
\text { and Sulieman Bani-Ahmad (2010) }\end{array}$ & $\begin{array}{l}\text { K-Means } \quad \text { Clustering } \\
\text { Method }\end{array}$ & $\begin{array}{l}\text { Easily detection and } \\
\text { implementation. }\end{array}$ & $\begin{array}{l}\text { Needs to define the } \\
\text { value of cluster i.e. K }\end{array}$ \\
\hline $\begin{array}{l}\text { P. Kumsawat et al. (2008) } \\
\text { Mr. V. A. Gulhane \& Dr. A. A. } \\
\text { Gurjar (2011) }\end{array}$ & $\begin{array}{l}\text { Neural Network Based } \\
\text { Method }\end{array}$ & $\begin{array}{l}\text { Use training data to } \\
\text { solve complex } \\
\text { problem and easily } \\
\text { detect errors. }\end{array}$ & $\begin{array}{l}\text { Training process } \\
\text { consumes more time } \\
\text { and it required over } \\
\text { training. }\end{array}$ \\
\hline
\end{tabular}

\section{VI.FEATURE EXTRACTION TECHNIQUES}

Feature extraction is an important step in image classification. It allows to represent the content of the image as perfect as possible. In feature extraction, phase features contain the segmented image has been extracted on the basis of their color, shape \& texture ${ }^{[32]}$. Some feature extraction techniques used for plant leaf diseases is discussed in below.

i. Texture Based Feature Extraction: - GLCM (Gray Level Co-occurrences Matrix) is good texture-based feature extraction method which is more efficient to extract statistical based feature more efficiently. These spatial features are indicating pixel relationship based on gray scale intensity and orientation. Formulas of all statistical features (equations 15-22) are discussed below ${ }^{[33],[34]}$.

$$
\begin{aligned}
& \operatorname{Corelation}\left(f_{1}\right)=\frac{\sum_{i} \sum_{j}(i j) p(i, j)-\mu_{x \mu_{y}}}{\sigma_{x} \sigma_{y}} \\
& \text { Entropy }\left(f_{2}\right)=\sum_{i} \sum_{j} p(i, j) \log (p(i, j)) \\
& \operatorname{Variance}\left(f_{3}\right)=\sum_{i} \sum_{j}(i-\mu)^{2} p(i, j) \\
& \text { Homoginity }\left(f_{4}\right)=\sum_{i, j=0}^{N-1} \frac{p_{i, j}}{1+(i-j)^{2}} \\
& \text { Angular Second Moment }\left(f_{5}\right)=\sum_{i, j=0}^{N-1}\left(p_{i j}\right)^{2} \\
& \operatorname{Contrast}\left(f_{6}\right)=\sum_{i, j=0}^{N-1} p_{i j}(i-j)^{2} \\
& \text { Energy }\left(f_{7}\right)=\sum_{i, j=0}^{N-1}\left(p_{i j}\right)^{2} \\
& \operatorname{Mean}\left(f_{8}\right)=\sum_{i, j=0}^{N-1} i_{i j}
\end{aligned}
$$

Bindushree H. B., Dr. Sivasankari G. G. ${ }^{[35]}$ used texture-based features extraction method to describe the plant leaf diseases.

ii. Shape Based Feature Extraction: - The area (A) and perimeter (P) of disease spots were calculated from the binary image of disease spot. The minimum enclosing rectangle (MER) of a diseased spot was obtained by the method of rotating an image with same angle. The long axis length and short axis length of MER represented the length (1) and width (w) of the diseased spot. The shape feature including rectangularity, compactness, elongation, and roundness were calculated using area, perimeter, MER, of the diseased spot found in rice leaf image by Qing Yao et al. ${ }^{[14]}$. Lesion shape and lesion color feature of disease spot has also been used in the detection of disease in paddy leaves. A method is discussed to calculated percentage of diseased infected area ${ }^{[6],[29]}$ below,

$>$ Percentage of disease infected area (PI): - In shape feature extraction, the percentage of leaf area can be calculated. Percentage of infected area can be calculated by using the equation (23), 


$$
P I=\frac{A_{d}}{A_{t}} * 100
$$

Where $A_{d}=$ Diseased Area, $A_{t}=$ Total Area

iii. Color-Based Feature Extraction: - In order to extract the feature based on color, color moment method, color co-occurrence method is a most popular method to extract the feature of an image on the basis of its color. In Color Moment Method first, the RGB color space is converted to a suitable color space like HIS color space where the color features are extracted more efficiently. Then, consider 3 color moments where moment 1 is for mean, moment 2 is for standard deviation, moment 3 is for skewness for each plane ${ }^{[36]}$. These 9 color moments feature vector has been used for characterizing Tomato ${ }^{[17]}$, Maize ${ }^{[13]}$, Apple ${ }^{[5]}$, and Cotton ${ }^{[10]}$ leaf images.

iv. Other Feature Extraction Method: - There is a different kind of feature extraction method found in image processing like they are a combination of two feature extraction techniques like color $\&$ texture, texture $\&$ shape, shape \& color $^{[48]}$.

$>$ Color Co-occurrence Method: - In this feature extraction method, both color and texture of an image have considered. Malik Barik et al. ${ }^{[18]}$ used this feature extraction method to describe the image more perfectly. The CCM texture analysis technique was developed through the use of spatial gray level dependence matrices or called as SDGM (Spatial Domain Gray-level Matrix).

> Discrete Wavelength Transform: - Wavelet Transform decomposes the signal into some basic functions known as wavelets. The capability for multi-resolution analysis wavelet transform can be used for analyzing details of an image at various scales. Detail components contain information of diagonal, vertical, and horizontal sub-band of the image ${ }^{[37]}$. This information can be extracted by using high-pass and low-pass filter $^{[38]}$

$>$ Discrete Cosine Transform: - DCT is a frequency domain method that is helpful in finding energy at various spectral sub-bands (blocks) of the image. The local DCT method uses a range of 2-dimensional DCT to construct a feature vector of an image. The main advantage of this method is its efficiency. In transforming the spatial domain into the frequency domain, blocked DCT is used in which transformation is performed in an efficient manner. Secondly, DCT works with entirely real-valued components, in term of image compression. DCT has good de-correlation and energy compaction characteristics.

So, summarizations of feature extraction techniques are illustrated below in Table 6 .

Table 6. Summary of different feature extraction techniques

\begin{tabular}{|c|c|c|}
\hline Authors Name & Proposed Methodology & Used Technique \\
\hline Dr. Sivasankari G. G. \& Bindushree H. B. (2015) & Texture Based Feature Extraction & GLCM \\
\hline Qing Yao, Zexin Guan et al. (2009) & Shape Based Feature Extraction & MER \\
\hline $\begin{array}{l}\text { Patil J. K. and Raj Kumar (2012) } \\
\text { Mr. V. A. Gulhane, Dr. A. A. Gurjar (2011) } \\
\text { Jayamala K. Patil, Raj Kumar (2011) } \\
\text { Jie TIAN, Qiuxia HU (2012) }\end{array}$ & Color-Based Feature Extraction & CMM \\
\hline $\begin{array}{l}\text { Dheeb Al Bashish, Malik Braik et al. (2010) } \\
\text { Asma Akhtar, Aasia Khanum et al. (2013) } \\
\text { Nawazish Naveed et al. (2011) }\end{array}$ & Other Feature Extraction Method & $\begin{array}{l}\text { CCM } \\
\text { SDGM } \\
\text { DWT } \\
\text { DCT }\end{array}$ \\
\hline
\end{tabular}

\section{Classification TechniQues}

Image classification is one of the most complex steps in image processing and also it is an important process in pattern recognition. For classification phase, different kind of machine learning techniques is used to assign a class to a set of unclassified data. The percentage of accuracy in pattern recognition was described by the classification process.

i. K-Nearest Neighbour (KNN): - The K-Nearest Neighbour is a kind of classifier which can train and test data at the same time. KNN classifier is instance based classified that performs classification of unknown instances by relating unknown to known by using distance or similarities function. It takes $\mathrm{K}$ nearest point and then assigns a class of majorities to the unknown instance ${ }^{[37]}$.

ii. Support Vector Machine (SVM): - Support Vector Machine is mostly used machine learning technique basically used for classification process. SVM is a kernel based classifier; initially, it was implemented for linear separation which has able to classify data into two classes only. SVM has been used for several 
realistic problems such as face recognition ${ }^{[40]}$, cancer diagnosis ${ }^{[41]}$. Multiclass SVM is deployed for grape leaf ${ }^{[23]}$ disease classification.

iii. Naïve Bayes Classifier: - Navies Bayes Classifier is usually known as a statistical classifier. Its foundation is on Bayes' theorem and uses probabilistic analysis for classification. Naïve Bayesian Classifier gives more accurate results in a less computational time when applied to the large datase ${ }^{[39]}$.

iv. Decision Tree: - Decision Tree classifiers are being successfully used in many areas including speech recognition, medical diagnosis, character recognition etc. Decision tree classifiers have the ability to convert the complex decision into understandable and easy decisions ${ }^{[42]}$.

v. Recurrent Neural Network (RNN): - The Recurrent Neural Network includes feedback connection. In contrast to feed-forward networks, the dynamical properties are more significant. The neural network has evolvement within a constant state and the activation values of any units do not change anymore. But some exceptions are also found like according to required scenario, it is important to change the activation value of the resultant or output neurons ${ }^{[43]}$. BPNN (Back Propagation Neural Network), FFNN (Feed Forward Neural Network) are a most common example of Recurrent Neural Network. Neural Network is also deployed for leaf disease classification ${ }^{[47]}$.

Table 7. Summary of different classification technique

\begin{tabular}{|c|c|c|c|}
\hline Authors Name & Proposed Methodology & Advantages & Disadvantages \\
\hline $\begin{array}{l}\text { Mohammed J. } \\
\text { Islam et al. (2007) }\end{array}$ & $\begin{array}{l}\text { K-Nearest Neighbour } \\
(\mathrm{KNN})\end{array}$ & $\begin{array}{l}\text { i) Low cost and effort } \\
\text { for learning process. }\end{array}$ & $\begin{array}{l}\text { i) Computationally expensive to } \\
\text { find the } K \text { neighbours when } \\
\text { sample dataset is large. } \\
\text { ii) Performance depends on the } \\
\text { number of dimensions. }\end{array}$ \\
\hline $\begin{array}{l}\text { Asma Akhtar et al. } \\
\text { (2013) }\end{array}$ & Naïve Bayes Classifier & $\begin{array}{l}\text { i) Conceptually very } \\
\text { easy to understand. }\end{array}$ & $\begin{array}{l}\text { i) Class conditional } \\
\text { independence, therefore loss of } \\
\text { accuracy. } \\
\text { ii) Practically, dependencies } \\
\text { exists among variables. }\end{array}$ \\
\hline $\begin{array}{l}\text { P. Kumsawat et al. } \\
\text { (2008) }\end{array}$ & $\begin{array}{l}\text { Support Vector Machine } \\
(\text { SVM) }\end{array}$ & i) $\begin{array}{l}\text { Reduced } \\
\text { computational } \\
\text { complexity. }\end{array}$ & $\begin{array}{l}\text { i) Training is time consuming. } \\
\text { ii) Structure is difficult } \\
\text { to understand. } \\
\text { iii) Accuracy may depend on the } \\
\text { number of classes. }\end{array}$ \\
\hline $\begin{array}{l}\text { Mohamed } \\
\text { (2005) }\end{array}$ & Decision Tree & $\begin{array}{l}\text { i) No extensive design } \\
\text { and training. } \\
\text { ii) Reduced } \\
\text { computational time. }\end{array}$ & $\begin{array}{l}\text { i) Complex calculation. } \\
\text { ii) Accuracy depends } \\
\text { fully on feature } \\
\text { selection. }\end{array}$ \\
\hline Pearl Mutter (1990) & $\begin{array}{ll}\text { Recurrent } & \text { Neural } \\
\text { Network (RNN) } & \end{array}$ & $\begin{array}{ll}\text { i) } & \text { Handles noisy } \\
& \text { input. } \\
\text { ii) } & \text { Self adaptive } \\
& \text { technique. } \\
\end{array}$ & $\begin{array}{l}\text { i) Training is time taking. } \\
\text { ii) Difficult to handle } \\
\text { network architecture. }\end{array}$ \\
\hline
\end{tabular}

So, summarizations of different classification techniques are illustrated below in Table 7.

The following graph shows the summary of the literature survey based on the year of publication with accuracy Graph-1 and classification tool used with accuracy Graph-2. 


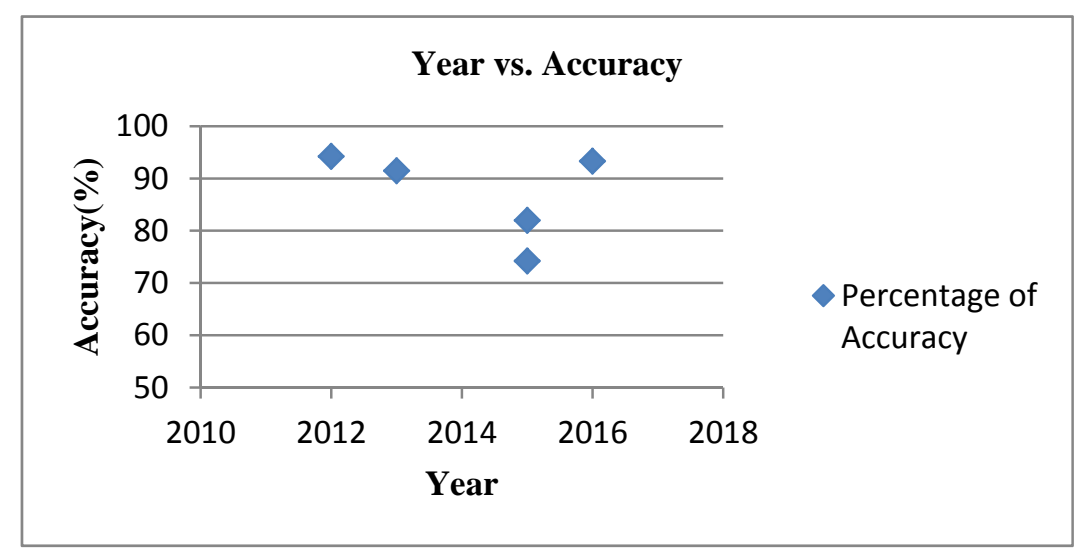

Graph 1- Comparison of year of publication with Accuracy Names of the Classifier

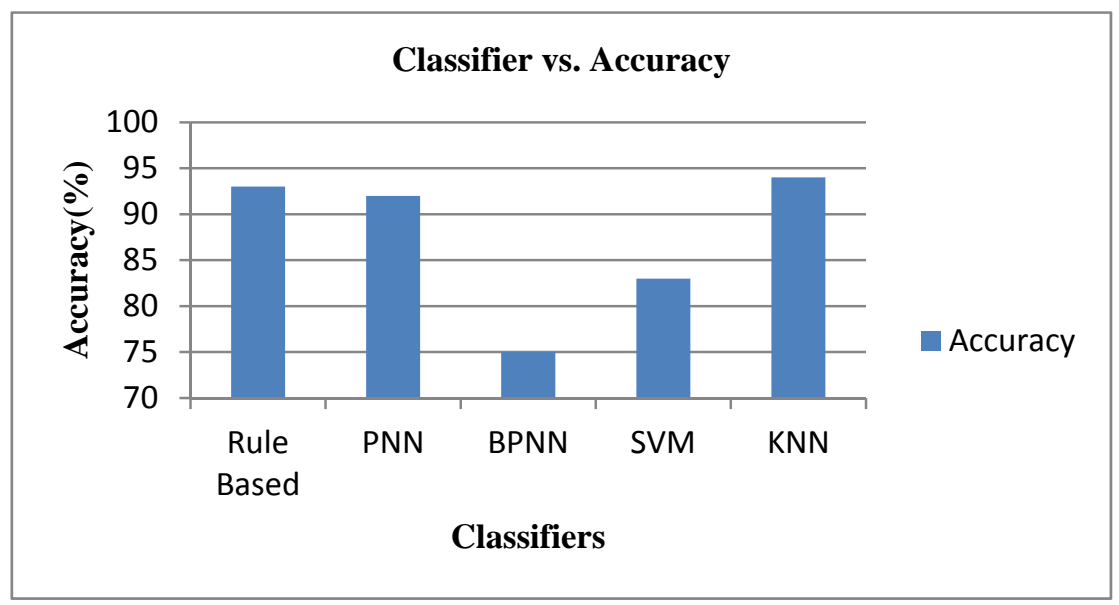

Graph 2- Comparison of Names of the Classifier with Accuracy of that Classifier

VIII. QUANTIFICATION TECHNIQUES

By the use of different quantification technique, the severity of disease found on leaves can be evaluated. It is also very important part of disease detection using image processing techniques.

i. Juhua Luo et al. ${ }^{[44]}$, the severity of the disease can be measured by the Canopy Spectral Data Analysis. The canopy spectral measurements were taken by the ASD field spec pro spectrometer fitted with $25^{\circ}$ field of view fiber optics. Simultaneously the disease index is measured by using equation (24) given below,

$$
D I(\%)=\frac{\sum(x * f)}{n * \sum f} * 100
$$

Where ' $\mathrm{f}$ ' is the total number of leaves of each degree of disease severity, ' $\mathrm{x}$ ' is incidence level and ' $\mathrm{n}$ ' is the light incidence level.

ii. Rashedul Islam, Md. Rafiqul Islam ${ }^{[45]}$, they proposed a method to measure the severity of disease found on paddy leaf. First, the input leaf image is segmented using K-Means segmentation, then the cluster contains healthy and diseased portion will be converted to a binary image. From that binary image, white pixel contains by the both cluster has been calculated because that white pixel will help to calculate a number of pixels affected by the leaf disease. The percentage of the infected pixel can be calculated by equation (25).

$$
P_{A}(\%)=\frac{w p_{a}}{P_{l}} * 100
$$

Where $w p_{a}=$ Total number of white pixels in the affected region of leaf, $P_{l}=$ Total pixel of the leaf area

iii. Wanrat Abudullakasim et al. suggest a digital image analysis technique measure the severity of brown spot leaf disease found cassava crop ${ }^{[6]}$. Jimita Bhagel and Prashant Jain also used this method to measure the severity of leaf disease found ${ }^{[49]}$. According to their developed prototype, the input RGB leaf image is converted to HIS color space, and then the infected pixels are extracted from the healthy portion of Hue image on basis of hue difference. After that percentage of disease severity has been measured by the help the equation (26).

$$
P I=\frac{A_{d}}{A_{t}} * 100
$$

Where $A_{d}=$ Diseased Area, $A_{d}=$ Total Area 
iv. Sumeet S. Nisale et al. ${ }^{[12]}$, develop an algorithm to measure the leaf disease severity due to mineral deficiency found on Groundnut plant. First find the stages of deficiencies and then gradually geometric moment algorithm apply to each leaf. This data can be used by the device to tell the type and stage of deficiency of the leaf being tested. This shows better result and minimizes the need for complex algorithms like texture analysis or shape analysis.

v. C. H. Bock, G. H. Poole et al. ${ }^{[46]}$, approach measurement of disease severity using hyperspectral imaging technique. This technique is also known as imaging spectroscopy, is a technology has received broad in agriculture research. HS imaging creates a large amount of data order of hundreds Mb per image which contains by hypercube. Then image pre-processing will take place. After the completion of this phase, the data can proceed. Although analysis of data may take many forms, one of the most common techniques is to classify the image pixels on the basis of statistical similarities. This is referred as supervised classification.

vi. Sanjay B. Patil et al. also used Triangle method of the thresholding to measure the severity of brown spot leaf disease found sugar cane crop ${ }^{[16]}$. The disease severity of the plant leaves is measured by the lesion area and leaf area ratio. Using image processing method it can be expressed as below,

$$
S=\frac{A_{d}}{A_{l}}
$$

Where $A_{d}=$ Diseased Leaf Area, $A_{l}=$ Total Leaf Area

So, summarizations of quantification techniques are illustrated below in Table 8 .

Table 8. Summary of different quantification methods

\begin{tabular}{|l|l|l|}
\hline \multicolumn{1}{|c|}{ Authors Name } & \multicolumn{1}{|c|}{ Proposed Methodology } & \multicolumn{1}{c|}{ Applications } \\
\hline Juhua Luo et al. (2014) & $\begin{array}{l}\text { Canopy Spectral Data } \\
\text { Analysis }\end{array}$ & $\begin{array}{l}\text { The current analysis detected middle-stage disease } \\
\text { in the crops, which leaves a need for discovering } \\
\text { methods for detecting and recognizing disease in the } \\
\text { earliest stages. }\end{array}$ \\
\hline $\begin{array}{l}\text { Rashedul Islam, Md. } \\
\text { Rafiqul Islam (2015) }\end{array}$ & Pixel Calculation & $\begin{array}{l}\text { The proposed method is only experimented on } \\
\text { disease in the paddy crops. Need to develop a } \\
\text { common system to measure disease severity of the } \\
\text { leaves of other crops. }\end{array}$ \\
\hline $\begin{array}{l}\text { Wanrat Abudullakasim } \\
\text { et al. (2012) }\end{array}$ & Area Diagram Key & $\begin{array}{l}\text { This technique was developed to identify severity of } \\
\text { brown leaf spot disease. }\end{array}$ \\
\hline $\begin{array}{l}\text { Sumeet S. Nisale et al. } \\
\text { (2011) }\end{array}$ & $\begin{array}{l}\text { Geometric } \\
\text { Algorithm }\end{array}$ & $\begin{array}{l}\text { Technique design for diagnosis of deficiencies in the } \\
\text { mineral levels affecting a groundnut plant. }\end{array}$ \\
\hline $\begin{array}{l}\text { C. H. Bock, G. H. H. } \\
\text { Poole et al. (2010) }\end{array}$ & $\begin{array}{l}\text { Hyperspectral } \\
\text { Technique }\end{array}$ & $\begin{array}{l}\text { Still a new technology not fully tested or adapted to } \\
\text { the needs of plant disease severity assessment. } \\
\text { Not established how to deal with multiple diseases } \\
\text { but offer more possibilities. }\end{array}$ \\
\hline
\end{tabular}

\section{IX.CONCLUSION}

Detection and diagnosis of disease is the most important tasks in image processing. So, this paper represents an approach taken by researchers for detection and recognition of plant leaf diseases which is illustrated below in Table 9. In this survey paper has briefly explained the various techniques used for the purpose of detection and diagnosis including advantages and disadvantages. Among all these different techniques best techniques will be analyzed who have the maximum benefits. But in spite of the maximum benefits every technique has certain limitations like variety of methods have been developed; there is still no general method or common system which is suitable for detection and diagnosis any type of disease. So to overcome the drawback of different techniques fusion of different techniques is a good idea. 
Table 9. Summarization of studies on plant disease recognition \& classification using image processing \& soft computing techniques

\begin{tabular}{|c|c|c|c|c|}
\hline Plant & Disease/Deficiency & $\begin{array}{l}\text { Device used for } \\
\text { Image Acquisition }\end{array}$ & $\begin{array}{l}\text { Methods used for } \\
\text { Recognition/ } \\
\text { Classification/ } \\
\text { Quantification }\end{array}$ & $\begin{array}{l}\text { Authors } \\
\text { \& Year }\end{array}$ \\
\hline Rice & $\begin{array}{l}\text { Brown-Spot Disease (BSD), } \\
\text { Blast Disease (BD), and } \\
\text { Narrow Brown-Spot Disease } \\
(\text { NBSD) [2] }\end{array}$ & $\begin{array}{l}\text { CCD color camera } \\
(\text { Nikon D80) }\end{array}$ & GLCM, SVM & Qing Yao (2009) \\
\hline Apple & $\begin{array}{l}\text { Apple mosaic, Apple rust, and } \\
\text { Apple Alternaria leaf spot }\end{array}$ & Canon IXUS850 IS & KPCA, GA-SVM & Jie Tian (2012) \\
\hline Cassava & Brown leaf spot & $\begin{array}{l}\text { Digital camera } \\
\text { (IXY55 model) }\end{array}$ & Otsu's method & $\begin{array}{l}\text { Kittipong } \\
\text { Powbunthorn } \\
(2012) \\
\end{array}$ \\
\hline Citrus & Citrus canker & N/A & $\begin{array}{l}\text { Local LBPH, Ada } \\
\text { Boost Classifier }\end{array}$ & $\begin{array}{l}\text { Min Zhang } \\
(2010)\end{array}$ \\
\hline Cotton & $\begin{array}{l}\text { Bacterial disease, } \\
\text { Fungal diseases, } \\
\text { Viral disease }\end{array}$ & $\mathrm{N} / \mathrm{A}$ & SOFM, GA & $\begin{array}{l}\text { Mr. Viraj A. } \\
\text { Gulhane (2011) }\end{array}$ \\
\hline Ground Nut & $\begin{array}{l}\text { iron, zinc and magnesium } \\
\text { deficiencies }\end{array}$ & $\mathrm{N} / \mathrm{A}$ & Geometric Moments & $\begin{array}{l}\text { Sumeet S. Nisale } \\
(2011)\end{array}$ \\
\hline Maize & $\begin{array}{l}\text { Gray spot \& common rust } \\
\text { disease }\end{array}$ & $\mathrm{N} / \mathrm{A}$ & $\begin{array}{l}\text { Histogram Moments } \\
\text { \& CCM }\end{array}$ & Patil J.K. (2012) \\
\hline Cotton & Leaf Crumple, Red Spots & N/A & $\begin{array}{l}\text { Eigen Spectrum } \\
\text { Modeling }\end{array}$ & $\begin{array}{l}\text { Viraj A. Gulhane } \\
\text { (2012) }\end{array}$ \\
\hline Rice & $\begin{array}{lll}\text { Brown-Spot } & \text { Disease, } & \text { Blast } \\
\text { Disease } & & \\
\end{array}$ & $\begin{array}{l}\text { Nikon COOLPIX } \\
\text { P4 }\end{array}$ & $\begin{array}{l}\text { Morphological } \\
\text { Operations, SVM }\end{array}$ & $\begin{array}{l}\text { S. Phadikar } \\
(2012)\end{array}$ \\
\hline Sugarcane & Brown spot disease & $\mathrm{N} / \mathrm{A}$ & $\begin{array}{l}\text { Triangle } \\
\text { Thresholding Method }\end{array}$ & $\begin{array}{l}\text { Sanjay B. Patil } \\
(2011)\end{array}$ \\
\hline Tomato & $\begin{array}{l}\text { Tomato Early Blight, Late } \\
\text { Blight Septoria Leaf Spot }\end{array}$ & $\mathrm{N} / \mathrm{A}$ & Color moments & $\begin{array}{l}\text { Jayamala K. Patil } \\
(2011)\end{array}$ \\
\hline $\begin{array}{l}\text { Rose, bean, } \\
\text { lemon and } \\
\text { banana } \\
\text { leaves }\end{array}$ & $\begin{array}{l}\text { Early scorch, } \\
\text { Yellow spots, brown spots and } \\
\text { late scorch }\end{array}$ & $\begin{array}{l}\text { Common Digital } \\
\text { Camera }\end{array}$ & SVM & $\begin{array}{l}\text { Arivazhagan et } \\
\text { al. (2013) }\end{array}$ \\
\hline Cucumber & $\mathrm{N} / \mathrm{A}$ & $\mathrm{N} / \mathrm{A}$ & $\begin{array}{l}\text { Support Vector } \\
\text { Machine }\end{array}$ & $\begin{array}{l}\text { Youwen et al. } \\
(2008)\end{array}$ \\
\hline Grape & Stripe rust and leaf rust & $\begin{array}{l}\text { Common Digital } \\
\text { Camera }\end{array}$ & $\mathrm{CCM}$ and $\mathrm{NN}$ & $\begin{array}{l}\text { Sannakki et al. } \\
(2013)\end{array}$ \\
\hline $\begin{array}{l}\text { Oil Palm } \\
\text { Plant }\end{array}$ & Nutrient deficiencies & $\begin{array}{l}\text { Camera Lumix- } \\
\text { LX5 Panasonic }\end{array}$ & Fuzzy classifier & $\begin{array}{l}\text { Hirudin et al. } \\
(2011)\end{array}$ \\
\hline
\end{tabular}

\section{REFERENCES}

[1] Bani-Ahmad S, Al-Hiary H, ALRahamneh Z, Reyalat M, Barik M. Fast and Accurate Detection and Classification of Plant Diseases. International Journal of Computer Applications. March 2011. Volume 17-No.1; 0975-8887.

[2] Jasmeet Kaur, Dr.Raman Chadha, Shvani Thakur, Er.Ramanpreet Kaur. A Review Paper on Plant Disease Detection using Image Processing and Neural Network Approach. International Journal of Engineering Sciences \& Research Technology. April, 2016. ISSN: 2277-9655.

[3] Diptesh Majumdar, Dipak Kumar Kole, Aruna Chakraborty, Dwijesh Dutta Majumder. REVIEW: DETECTION \& DIAGNOSIS OF PLANT LEAF DISEASE USING INTEGRATED IMAGE PROCESSING APPROACH. International Journal of Computer Engineering and Applications. June 2014. Volume VI; Issue- III.

[4] Arnal Barbedo, Jayme Garcia. Image processing techniques for detecting, quantifying and classifying plant diseases. Barbedo Springer Plus; 2013.

[5] Jie TIAN, Qiuxia HU, Xiaoyi MA, Mingyu HAN. An Improved KPCA \& GA-SVM. Classification Model for Plant Leaf Disease Recognition. Journal of Computational Information Systems. 2012; 7737-7745.

[6] Kittipong Powbunthorn, Wanrat Abudullakasim, Jintana Unartngam. Assessment of the Severity of Brown Leaf Spot Disease in Cassava using Image Analysis. The International conference of the Thai Society of Agricultural Engineering. Agust 4,2012.

[7] Min Zhang, Qinggang Meng (2010). Citrus canker detection based on leaf images analysis. 978-1-4244- 7618-3/10, IEEE. 
[8] J. Belasque, Jr., M. C. G. Gasparoto. Detection of mechanical and disease stresses in citrus plants by fluorescence spectroscopy. April 2008. APPLIED OPTICS / Vol. 47, No. 11 / 10.

[9] Emery C. Lins et al. Detection of citrus canker in citrus plants using laser induced fluorescence spectroscopy. Precision Agric. June 2009. DOI 10.1007/s11119-009-9124-2.

[10] Mr. V. A. Gulhane \& Dr. A. A. Gurjar. Detection of Diseases on Cotton Leaves and Its Possible Diagnosis. International Journal of Image Processing. 2011; Volume (5): Issue (5): 2011590.

[11] Viraj A. Gulhane, Ajay A. Gurjar. Diseases Classification on Cotton leaves by Advance Digital Image Processing Approach. IJCA. National Conference on Innovative Paradigms in Engineering \& Technology. 2012.

[12] Chandan J. Bharambe, Vidya N.More, Sumeet S. Nisale. Detection and Analysis of Deficiencies in Groundnut Plant using Geometric Moments. World Academy of Science. Engineering and Technology International Journal of Biological, Agricultural, Biomolecular, Food and Biotechnological Engineering. 2011, Vol:5, No:10.

[13] Patil J. K. and Raj Kumar. Feature Extraction of Diseased Leaf Images. Journal of Signal and Image Processing. 2012, Volume 3, Issue 1, ISSN: 0976-8882 \& E-ISSN: 0976-8890.

[14] Qing Yao, Zexin Guan et al. Application of SVM for detecting rice diseases using shape and color texture features. IEEE 2012. DOI 10.1109/ICEC.2009.73.

[15] S. Phadikar, J. Sil, and A. K. Das. Classification of Rice Leaf Diseases Based on Morphological Changes. 2012, Vol. 2, No. 3. International Journal of Information and Electronics Engineering.

[16] Sanjay B. Patil et al. LEAF DISEASE SEVERITY MEASUREMENT USING IMAGE PROCESSING. 2012, Vol.3 (5), $297-301$. International Journal of Engineering and Technology.

[17] Jayamala K. Patil, Raj Kumar. Color Feature Extraction of Tomato Leaf Diseases. International Journal of Engineering Trends and Technology. 2011, ISSN: 2231-5381, Volume2, Issue2.

[18] Dheeb Al Bashish, Sulieman Bani-Ahmad, and Malik Braik. A Framework for Detection and Classification of Plant Leaf and Stem Diseases. IEEE 2010. 978-1-4244-8594-9/10.

[19] Sannakki S. S. et al. (2013). Diagnosis and Classification of Grape Leaf Diseases using Neural Networks. In proceeding of 4th International Conference (ICCCNT). IEEE, Tiruchengode, 1-5. DOI: 10.1109/ICCCNT.2013.6726616.

[20] Sanjeev S Sannakki et al. Leaf Disease Grading by Fuzzy Logic and Machine Vision, Int. J. Comp. Tech. Appl. 2011, Vol 2 (5), 1709-1716, ISSN:2229-6093.

[21] Sidnei Alves de Araújo and Hae Yong Kim, Grayscale Template-Matching Invariant to Rotation, Contrast, Brightness, Translation, and Scale.

[22] S. Ananthi and S. Vishnu Varthini. DETECTION AND CLASSIFICATION OF PLANT LEAF DISEASES. IJREAS. 2012, Volume 2, Issue 2, ISSN: 2249-3905.

[23] P. Kumsawat et al. Grape Leaf Disease Detection from Color Imaginary Using The Tybrid Intelligent System. IEEE 2008. 978-14244-2101-5/08.

[24] A. Camargo, J.S. Smith. An image-processing based algorithm to automatically identify plant disease visual symptoms. Biosystems Engineering. doi:10.1016/j.biosystemseng.2008.09.030.

[25] Piyush Chaudhary et al. Transformation of Color Based Approach for Disease Spot Detection on Plant Leaf. International Journal of Computer Science and Telecommunications. 2012, Volume 3, Issue 6.

[26] S. S. Sannakki, V. S. Rajpurohit. An Approach for Detection and Classification of Leaf Spot Diseases Affecting Pomegranate Crop. International Journal of Advance Foundation and Research in Computer. January 2015, Volume 2, Special Issue (NCRTIT 2015), ISSN $2348-4853$

[27] Mr. V. A. Gulhane \& Dr. A. A. Gurjar. Detection of Diseases on Cotton Leaves and Its Possible Diagnosis. IJIP (International Journal of Image Processing). Volume (5): Issue (5): 2011.

[28] A Threshold Selection Method from Gray-Level Histograms. IEEE TRANSACTIONS ON SYSTEMS, CYBERNETICS, \& MAN. VOL. SMC-9, NO. 1.

[29] Dheeb Al Bashish, Sulieman Bani-Ahmad, and Malik Braik. A Framework for Detection and Classification of Plant Leaf and Stem Diseases. IEEE 2010. 978-1-4244-8594-9/10.

[30] Prabira Sethy, Baishalee Negi, Nilamani Bhoi. Detection of Healthy \& Defected Diseased Leaf of Rice Crop Using K-Means Clustering Technique. International Journal of Computer Applications. January 2017, Volume 157- No.1, 0975-8887.

[31] R. Revathy, S.A. Chennakesavan. Threshold Based Approach for Disease Spot Detection on Plant Leaf. Transactions on Engineering and Sciences. Vol.3, Issue 5, ISSN: 2347-1964 (Online) 2347-1875 (Print).

[32] Aastha Tiwari, Anil Kumar, Goswami Mansi Saraswat. Feature Extraction for Object Recognition and Image Classification. International Journal of Engineering Research \& Technology (IJERT). Vol. 2 Issue 10, October - 2013. ISSN: 2278-0181.

[33] P. Mohanaiah et al. Image Texture Feature Extraction Using GLCM Approach. IJSR (Int. J. of Scientific and Research). May 2013. ISSN 2250-3153, Volume 3, Issue 5.

[34] A. Gebeje \& R. Huertas, Texture Characterization based on GLCM. ICTIC 2013.

[35] Dr. Sivasankari G. G. \& Bindushree H. B. Detection of Plant Leaf Disease Using Image Processing Methods. INT. J. OF TECH. ENHANCEMENTS AND EMERGING ENGINEERING RESEARCH. 2015, VOL 3, ISSUE 04, ISSN 2347-4289.

[36] Hui Yu, Mingjing Lf. COLOR TEXTURE MOMENTS FOR CONTENT-BASED IMAGE RETRIEVAL. IEEE ICIP 2002.

[37] Asma Akhtar, Shoab A. Khan, Arslan Shaukat, Aasia Khanum. Automated Plant Disease Analysis (APDA): Comparison of Performance of Machine Learning Techniques. 978-1-4799-2293-2/13, 2013, IEEE DOI 10.1109/FIT.2013.19.

[38] Nawazish Naveed, Tae-Sun Choi M. and Arfan Jaffar. Malignancy and abnormality detection of mammograms using DWT features and ensembling of classifiers. International Journal of the Physical Sciences. 2011, Vol. 6(8), DOI: 10.5897/IJPS11.262, pp. 21072116, ISSN $1992-1950$.

[39] Mohammed J. Islam et al. (2007). Investigating the Performance of Naive- Bayes Classifiers and K- Nearest Neighbour Classifiers. IEEE 2007, 0-7695-3038-9/07, DOI 10.1109/ICCIT.2007.148.

[40] Jennifer Huang, Bernd Heisele, and Volker Blanz. Face Recognition Using Component-Based SVM Classification and Morphable Models. Springer-Verlag Berlin Heidelberg 2002. pp. 334-341.

[41] Terrence S. Furey et al. SVM classification and validation of cancer tissue sample using microarray expression date. Bioinformatics, vol. 16, no.10, 2000.

[42] Mohamed Aly (2005). A Survey on Multiclass Classification Methods.

[43] Pearl Mutter (1990). Dynamic Recurrent Neural Network.

[44] Qingsong Guan et al. New Optimized Spectral Indices for Identifying and Monitoring Winter Wheat Diseases, IEEE JOURNAL OF SELECTED TOPICS IN APPLIED EARTH OBSERVATIONS AND REMOTE SENSING. June 2014, Vol. 7, No. 6.

[45] Rashedul Islam, Md. Rafiqul Islam. An Image Processing Technique to Calculate Percentage of Disease Affected Pixels of Paddy Leaf. IJCA (International Journal of Computer Applications). August 2015. Volume 123 - No.12, 0975 - 8887. 
[46] C. H. Bock et al. (2010). Plant Disease Severity Estimated Visually by Image Analysis, Digital Photography, and Hyperspectral Imaging-Critical Reviews in Plant Sciences. 29: 2, 59 - 107, DOI: 10.1080/07352681003617285.

[47] A. B Patil, Sachin D. Khirade. Plant Disease Detection Using Image Processing. 2015 International Conference on Computing Communication Control and Automation. 2015 IEEE. DOI 10.1109/ICCUBEA.2015.153.

[48] Hairuddin MA, Baki S. R. S. et al. Overview of image processing approach for nutrient deficiencies detection in Elaeis Guineensis. IEEE 2011, In proceeding of International Conference on system engineering and technology. DOI:10.1109/ICSEngT.2011.5993432.

[49] Jimita Bhagel, Prashant Jain. K-Means Segmentation Method for Automatic Leaf Disease Detection. Int. Journal of Engineering Research and Application. ISSN: 2248-9622, Vol. 6, Issue 3, ( Part -5) March 2016, pp.83-86.

\section{AUTHOR PROFILE}

\begin{tabular}{|c|c|}
\hline & $\begin{array}{l}\text { Prabira Kumar Sethy has received his Master of Technology degree in } \\
\text { Communication Engineering from IIT (ISM) Dhanbad. He is working as Lecturer in } \\
\text { Electronics, SUIIT, Sambalpur University, Odisha. His interest of research area is } \\
\text { Image Processing. He has published more than } 20 \text { number of research article in } \\
\text { International Journal and Conferences. }\end{array}$ \\
\hline & $\begin{array}{l}\text { Baishalee Negi is a Post Graduate student of SUIIT, Sambalpur University. She has } \\
\text { few publications in areas Computer Vision and Image Processing. She is doing } \\
\text { research work in area of image processing. }\end{array}$ \\
\hline & $\begin{array}{l}\text { Santi Kumari Behera has received her Master of Technology degree in Computer } \\
\text { Science \& Engineering from NIT Rourkela. She is working as Assistant Professor in } \\
\text { Veer Surendra Sai University Of Technology, Odisha, India. Her research of interest is } \\
\text { Computer Graphics and Image Processing. }\end{array}$ \\
\hline & $\begin{array}{l}\text { Nalini Kanta Barpanda has already received Ph.D. in Engineering from the Sambalpur } \\
\text { University. He is working as Associate Professor at SUIIT, Sambalpur University, } \\
\text { Odisha. He has published over } 22 \text { number of research articles in various areas of } \\
\text { Performance Analysis of Communication Interconnection N/W, Wireless Sensor N/W, } \\
\text { Image Processing, and Internet of Things. }\end{array}$ \\
\hline & $\begin{array}{l}\text { Amiya Kumar Rath has already received Ph.D. in Computer Science from the Utkal } \\
\text { University, Odisha, India. He is working as Professor at Veer Surendra Sai University } \\
\text { of Technology, Odisha. He has published over } 70 \text { number of research articles in } \\
\text { various areas of Computer Science, concentrating on Artificial Intelligence, Image } \\
\text { Processing, and Embedded System. }\end{array}$ \\
\hline
\end{tabular}

